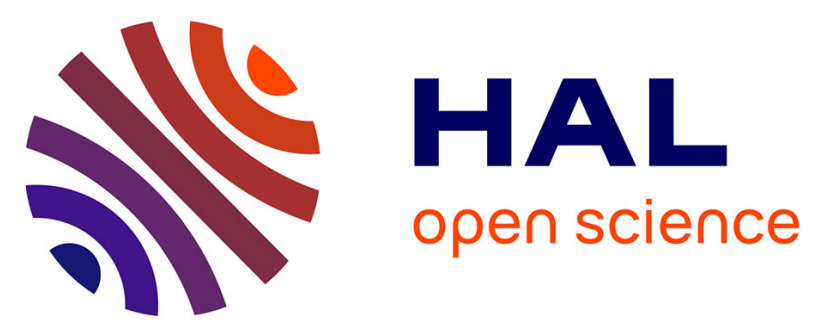

\title{
Bio-guided isolation of new phenolic compounds from Hippocrepis emerus flowers and investigation of their antioxidant, tyrosinase and elastase inhibitory activities
}

Marie Schmitt, Abdulmagid Alabdul Magid, Jane Hubert, Nicolas Etique, Laurent Duca, Laurence Voutquenne-Nazabadioko

\section{To cite this version:}

Marie Schmitt, Abdulmagid Alabdul Magid, Jane Hubert, Nicolas Etique, Laurent Duca, et al.. Bioguided isolation of new phenolic compounds from Hippocrepis emerus flowers and investigation of their antioxidant, tyrosinase and elastase inhibitory activities. Phytochemistry Letters, 2020, 35, pp.28-36. 10.1016/j.phytol.2019.10.014 . hal-02430970

\section{HAL Id: hal-02430970 \\ https://hal.univ-reims.fr/hal-02430970}

Submitted on 8 Oct 2021

HAL is a multi-disciplinary open access archive for the deposit and dissemination of scientific research documents, whether they are published or not. The documents may come from teaching and research institutions in France or abroad, or from public or private research centers.
L'archive ouverte pluridisciplinaire HAL, est destinée au dépôt et à la diffusion de documents scientifiques de niveau recherche, publiés ou non, émanant des établissements d'enseignement et de recherche français ou étrangers, des laboratoires publics ou privés. 
Bio-guided isolation of new phenolic compounds from Hippocrepis emerus flowers and investigation of their antioxidant, tyrosinase and elastase inhibitory activities

Marie Schmitt ${ }^{\mathrm{a}^{*}}$, Abdulmagid Alabdul Magid ${ }^{\mathrm{a}}$, Jane Hubert ${ }^{\# \mathrm{a}}$, Nicolas Etique ${ }^{\mathrm{b}}$, Laurent Duca ${ }^{\mathrm{b}}$, Laurence Voutquenne-Nazabadioko ${ }^{\mathrm{a}}$

${ }^{a}$ Université de Reims Champagne Ardenne, CNRS, ICMR UMR 7312, 51097 Reims, France b Université de Reims Champagne Ardenne, CNRS, MEDyC UMR 7369, 51097 Reims, France

\#a Current Address: NatExplore SAS, Prouilly, France

Correspondance to L. Voutquenne-Nazabadioko, Université de Reims Champagne Ardenne, CNRS, ICMR UMR 7312, 51097 Reims, France. Email: laurence.nazabadioko@univ-reims.fr 


\begin{abstract}
This study presents the bio-guided chemical investigation of a $80 \%$ methanol extract of Hippocrepis emerus flowers, a perennial non-climbing shrub. Liquid-liquid partitioning in solvents of increasing polarity combined to biological screening enabled to determine the EtOAc and $n-\mathrm{BuOH}$ soluble fractions as the most active parts of the extract. These fractions were chemically profiled by using a ${ }^{13} \mathrm{C}$ NMR-based dereplication method, resulting in the identification of twenty-six compounds. The dereplication process was completed by purification of some unknown or minor compounds of the $n-\mathrm{BuOH}$ fraction. Three new glycosylated flavonoids, namely kaempferol-3- $O$ - $\beta$-D-glucopyranosyl-7- $O-\beta-\mathrm{D}-$ glucopyranosyl-( $1 \rightarrow 3)$ - $\alpha$-L-rhamnopyranoside $(\mathbf{1})$, isorhamnetin-3- $O$ - $\beta$-D-glucopyranosyl-7$O$ - $\beta$-D-glucopyranosyl-( $(1 \rightarrow 3)-\alpha-\mathrm{L}-$-rhamnopyranoside (2) and quercetin-3-O- $\beta$-Dglucopyranosyl-7,4'-O- $\alpha$-L-dirhamnopyranoside (3), together with twelve known compounds (4 - 15) were isolated. Their structures were elucidated by spectroscopic methods including NMR, HR-ESI-MS and UV. The antioxidant activity of fractions and isolated compounds were evaluated using DPPH and hydroxyl radical scavenging and CUPRAC assays. In parallel, their inhibitory properties against mushroom tyrosinase and human neutrophil elastase enzymes were assessed. Three quercetin glycosides exhibited a significant radicalscavenging activity and two flavonoids showed a moderate elastase inhibitory activity.
\end{abstract}

\title{
Keywords
}

Flavonoid; dereplication; Hippocrepis emerus; antioxidant; tyrosinase; elastase. 


\section{Introduction}

Skin aging is a complex biological process influenced by oxidative stress and leading to matrix remodeling associated with hyperpigmentation phenomena. Prevention of these dynamic processes is a major issue for the dermo-cosmetics sector and substantial research efforts are being made to discover new protective ingredients (Parvez et al., 2007, Pandel et al., 2013, Kanlayavattanakul et al., 2018). Plants contain a wide range of secondary metabolites, which are commonly used as active molecules in pharmaceuticals or herbal cosmetics (Xu et al., 2009, Abdul Karim et al., 2014, Srinivas et al., 2015, Fierascu et al., 2018, Mukherjee et al., 2011). Plant extracts can contain high concentration of phenolic compounds (phenolic acids, flavonoids, anthocyanidins) that act as strong $H$-donors, reducing agents or oxygen quenchers, retarding the aging process. The antioxidant potency of these phenolic compounds can be easily determined by biochemical tests such as DPPH assay, the ferric reducing/antioxidant power (FRAP) assay, the ABTS assay or the cupric ion reducing antioxidant capacity (CUPRAC) assay (Fierascu et al., 2018). Flavonoids and other phenolics have also been reported as potent whitening agents due to their tyrosinase inhibitory activity (Parvez et al., 2007, Kanlayavattanakul et al., 2018) and some of them could play a role in matrix remodeling via an elastase inhibitory effect (Xu et al., 2009). For example, kaempferol and quercetin are flavonols showing skin healing effect (Mukherjee et al., 2011, Sharafzadeh et al., 2013) and consequently, various topical delivery systems of flavonoids have been studied (Nagula and Wairkar, 2019).

The papilionaceous corolla and leaves of Fabaceae species are a rich source of flavonoids and phenolic compounds. The genus Hippocrepis from the Fabaceae family comprises about twenty species, mostly occuring in the Mediterranean regions. The typical papilionaceous flowers are grouped into umbels or axillaries at the head of twigs, most often bright yellow and fragrant. Chemical investigations of the genus Hippocrepis have revealed the presence of flavonoids (Sherwood et al., 1973, Harborne, 1981, A1-Snafi, 2016), sterols (Komissarenko and Kovalev, 1988), coumarins (Piovan et al. 1996, Al-Snafi, 2016), cardiotonic glycosides, saponins (Al-Snafi, 2016), and sugars (Moyer et al., 1977). Hippocrepis species are traditionally used for their diuretic, purgative and heart-stimulating properties, but their dermo-cosmetic activities, including antioxidant properties, have not yet been studied.

Hippocrepis emerus (L.) Lassen (= Coronilla emerus L.) is a perennial non-climbing shrub species belonging to the subfamily Faboideae, tribe Loteae (Heywood and Ball, 1968, 
Lassen, 1989, Huang, 1998). It is quite common on the margins and in the gaps of broadleaved forests and in the supramediterranean maquis (Central and Southern Europe). In France, Hippocrepis emerus is a common species in the Mediterranean region, extending towards the west in the middle basin of the Garonne and in the Pyrenees (Lombard and Arnal, 2018). It is generally absent from highly disturbed ecosystems or markedly dry environments (Aronne et al., 2011). Some flavonoids have been isolated from the leaves and flowers of $H$. emerus (Harborne and Boardley, 1983), as well as furan derivatives phytoalexins after fungus inoculation (Dewick and Ingham, 1980), and saponins (Marquina and Figueras, 1952).

In this work, the chemical profile of $H$. emerus flowers was investigated using a ${ }^{13} \mathrm{C}$ NMR-based dereplication methodology combined to a bio-guided fractionation and purification procedure with a focus on phenolic compounds. The antioxidant, tyrosinase and elastase inhibitory activities of the crude $\mathrm{MeOH}$ extract, fractions and isolated compounds were evaluated.

\section{Results and discussion}

\subsection{Preliminary bio-guided evaluation of crude extract and fractions of H. emerus flowers}

A $80 \% \mathrm{MeOH}$ extract (HEM) was obtained from H. emerus flowers and partitioned successively in solvents of increasing polarity, resulting in a dichloromethane fraction (DCMF), ethyl acetate fraction (EAF) and $n$-butanol fraction (n-BF). The antioxidant potential of HEM and its fractions was estimated by three chemical assays, including the DPPH and hydroxyl radical assays to measure the ability to scavenge free radicals and the CUPRAC assay to evaluate their cupric reducing capacity. Their ability to inhibit mushroom tyrosinase and human neutrophil elastase activity was also tested. The results are shown in Table S1. For EAF and $n$-BF, a substantial cupric ion reducing capacity was observed ( IC $_{50}$ $2.8 \mu \mathrm{g} / \mathrm{mL}$ and $3.8 \mu \mathrm{g} / \mathrm{mL}$, respectively), as well as moderate DPPH (IC50 $71.7 \mu \mathrm{g} / \mathrm{mL}$ and $127.2 \mu \mathrm{g} / \mathrm{mL}$, respectively) and hydroxyl radicals scavenging activities ( IC $_{50} 239.3 \mu \mathrm{g} / \mathrm{mL}$ and $139.5 \mu \mathrm{g} / \mathrm{mL}$, respectively). A moderate tyrosinase inhibitory activity was also observed for EAF and $n$-BF ( IC $_{50} 212.0 \mu \mathrm{g} / \mathrm{mL}$ and $147.5 \mu \mathrm{g} / \mathrm{mL}$, respectively). Concerning the elastase inhibitory activity, HEM, DCMF, EAF and $n$-BF showed less than 5\% inhibition at 10 $\mu \mathrm{g} / \mathrm{mL}$. The EAF and $n$-BF showing the most interesting biological activities were chemically investigated through a bioassay-guided isolation strategy in order to tentatively determine the active constituents. 


\subsection{Chemical profiling of the EtOAc fraction (EAF)}

The major compounds of EAF were identified using a dereplication method combining Centrifugal Partition Chromatography (CPC) with NMR analyses and pattern recognition of metabolite spectral fingerprints, without purification of individual components (Hubert et al., 2014). The CPC fractionation of EAF was performed with the biphasic solvent system $\mathrm{MtBE} / \mathrm{CH}_{3} \mathrm{CN} /$ water $(3 / 3 / 4$, v/v/v) which was selected to recover moderately polar compounds. As a result, $23 \mathrm{CPC}$ sub-fractions $\left(\mathrm{EAF}_{1-23}\right)$ containing simplified mixtures or even pure compounds were obtained. After ${ }^{13} \mathrm{C}$ NMR analyses of $\mathrm{EAF}_{1-23}$, all spectra of the fraction series were processed and submitted to Hierarchical Clustering Analysis (HCA) for the recognition of ${ }^{13} \mathrm{C}$ NMR metabolite fingerprints. In this way, similarity measurements between ${ }^{13} \mathrm{C}$ NMR signals belonging to individual structures within the fraction series were visualized as "chemical shift clusters" on a HCA correlation heat map given in Fig. 1. As a result, 16 major chemical shift clusters colored in yellow were revealed on the heat map, corresponding to the major metabolites of the EAF (Fig. 1).

With the help of an in-house database containing predicted chemical shift values of natural metabolites, the correlated chemical shifts of cluster 1 in fractions $\mathrm{EAF}_{21-22}$ were assigned to pinitol. The identification of pinitol was easily confirmed by checking HSQC, HMBC and COSY data of fraction $\mathrm{EAF}_{21}$ and by comparison with literature data (Deans et al., 2018). By means of the same database search strategy, clusters 2 to 13 were identified as: p-hydroxybenzoic acid (Lee et al., 2012) and Z/E-p-coumaric acid (Torres-Naranjo et al., 2016) (cluster 2; fractions $\mathrm{EAF}_{4-6}$ ), a mixture of suberic acid and 3-nitropropionic acid (cluster 3; fractions $\mathrm{EAF}_{4-6}$ ), kaempferol-7-O- $\alpha$-L-rhamnopyranoside (11) (Ozden et al., 1998) (cluster 4; fractions $\mathrm{EAF}_{7-9}$ ), methyl benzoate and salicylic acid (cluster 5; fraction $\mathrm{EAF}_{3}$ ), oleic acid (Purcell et al., 1966) (cluster 6; fractions $\mathrm{EAF}_{1-2}$ ), rhamnocitrin-3-O- $\beta$-D-glucopyranoside (Bicha et al., 2016, Hu et al., 2017) (clusters 7 and 7', fraction $\mathrm{EAF}_{11}$ ), rhamnocitrin-3,4'-O- $\beta$ D-diglucopyranoside (Cui et al., 1993, Bicha et al., 2016) (clusters 8, 8' and 8"; fractions $\mathrm{EAF}_{18-19}$ ), saccharose (Deans et al., 2018) (cluster 9; fractions $\mathrm{EAF}_{21-22}$ ), a mixture of kaempferol-3-O- $\beta$-D-glucopyranoside (Xiao et al., 2006) and three 3-nitropropanoyl- $\beta$-Dglucopyranoses (corollin, coronillin and coronarian) (Moyer et al., 1977) (cluster 10; fraction $\mathrm{EAF}_{12}$ ), kaempferol (Xiao et al., 2006) (cluster 11; fractions $\mathrm{EAF}_{3-4}$ ), kaempferol-3-O- $\beta$-Dglucopyranosyl-7-O- $\alpha$-L-rhamnopyranoside (5) (Ozden et al., 1998) (cluster 12; fraction $\mathrm{EAF}_{17}$ ), and protocatechuic acid (Lee et al., 2012) (cluster 13; fraction $\mathrm{EAF}_{8}$ ). 
Among the compounds elucidated by dereplication, pinitol, $p$-hydroxybenzoic acid, suberic acid, kaempferol-7- $O$ - $\alpha$-L-rhamnopyranoside, rhamnocitrin-3- $O$ - $\beta$-D-glucopyranoside, rhamnocitrin-3,4'-O- $\beta$-D-diglucopyranoside and protocatechuic acid are reported here for the first time in the genus Hippocrepis. Three were previously isolated from H. emerus (methyl benzoate, kaempferol-3-O- $\beta$-D-glucopyranoside and kaempferol-3-O- $\beta$-D-glucopyranosyl-7$O$ - $\alpha$-L-rhamnopyranoside) (Harborne and Boardley, 1983, Joulain, 1983) and the seven other compounds were already known in the genus Hippocrepis (Joo et al., 1975, Moyer et al., 1977, Kovalev and Komissarenko, 1983, Kovac et al., 1986, Opletal and Sovovo, 1986, GuilGuerrero et al., 2017).

\subsection{Chemical profiling of $n-B u O H$ fraction $(n-B F)$}

The $n$-BF was composed of a very complex mixture of more polar metabolites as compared to the EAF. Therefore, five fractions ( $n$-BFA $-n$-BFE) were firstly produced from the $n$-BF on a Diaion HP-20 column in order to simplify its chemical composition and then evaluated for their biological activities. The results showed that $n$-BFD exhibited the best DPPH radical scavenging activity ( $\mathrm{IC}_{50} 87.7 \mu \mathrm{g} / \mathrm{mL}$ ), whereas $n$-BFC and $n$-BFD showed a good hydroxyl radical scavenging activity ( $\mathrm{IC}_{50} 130.7 \mu \mathrm{g} / \mathrm{mL}$ and $121.7 \mu \mathrm{g} / \mathrm{mL}$, respectively) and a significant cupric ion reducing power ( $\mathrm{IC}_{50} 2.3 \mu \mathrm{g} / \mathrm{mL}$ and $1.9 \mu \mathrm{g} / \mathrm{mL}$, respectively) (Table S1). For the tyrosinase inhibitory activity, $n$-BFC exhibited the best result ( $\mathrm{IC}_{50} 130.5 \mu \mathrm{g} / \mathrm{mL}$ ). The elastase inhibition of $n$-BFA - n-BFE oscillates between 20 and $28 \%$ at the dose 10 $\mu \mathrm{g} / \mathrm{mL}$. Comparing the activity of the $n$-BF with that of fractions $n$-BFA $-n$-BFE, we observed for $n$-BFD a substantial increase of DPPH and hydroxyl radicals scavenging activities and a higher cupric ion reducing power (Table S1). Thus, n-BFD was further chemically profiled by dereplication with the same NMR-based strategy as described for the EAF. As a result, $13 \mathrm{CPC}$ sub-fractions $\left(n-\mathrm{BFD}_{1-13}\right)$ containing simplified mixtures or even pure compounds were obtained. The resulting HCA heat map containing correlated ${ }^{13} \mathrm{C}$ NMR signals is also given in Fig. 1 and 10 major chemical shift clusters were revealed. The chemical shift values of clusters were assigned to $p$-hydroxybenzoic acid (clusters 2 and 2'; $n$ -

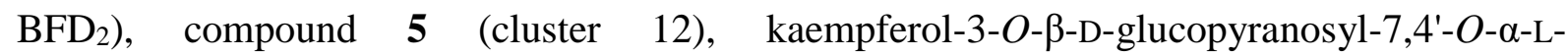
dirhamnopyranoside (4) (Harborne and Boardley, 1983) (clusters 14 and 14'; fraction $n$ $\mathrm{BFD}_{12}$ ), a mixture of kaempferol-3-O- $\beta$-D-apiofuranoside (Williams et al., 2019), quercetin-3$O$ - $\beta$-D-apiofuranoside (Williams et al., 2019) and quercetin-3-O- $\beta$-D-glucopyranosyl-7- $O-\alpha-\mathrm{L}-$ rhamnopyranoside (6) (Aboushoer et al., 2010) (cluster 15; fractions $n$-BFD 6 -10), benzyl- $\beta$-D- 
glucopyranoside (13) (Fujita et al., 1994) (clusters 16 and 16'; fraction $n$-BFD 6 ), and phenylethyl- $\beta$-D-glucopyranoside (14) (Bock and Pedersen, 1983) and (Z)-3-hexenyl- $\beta$-Dglucopyranoside (15) (Lee et al., 2012) (cluster 18; fraction $n$-BFD $4-6$ ). For the fraction $n$ $\mathrm{BFD}_{12}$, the database proposed an isorhamnetin tri-glycosylated, which could not be identified unambiguously (cluster 17).

Among the compounds elucidated by dereplication, quercetin-3-O- $\beta$-Dglucopyranosyl-7-O- $\alpha$-L-rhamnopyranoside, $\quad$ kaempferol-3- $O$ - $\beta$-D-glucopyranosyl-7- $O$ - $\alpha$-Lrhamnopyranoside and kaempferol-3-O- $\beta$-D-glucopyranosyl-7,4'-O- $\alpha$-L-dirhamnopyranoside were previously identified in H. emerus (Harborne and Boardley, 1983) and the six other were unknown in the genus Hippocrepis. The structure of the tri-substituted flavonoid 4 was hypothetically proposed in H. emerus flowers by Harborne and Boardley, 1983) based on UV analysis and acid hydrolysis without confirming the structural assignments by NMR and MS data.

As summarized in Table S1, $n$-BFD exhibited the highest antioxidant activity. In addition, $n$-BFD contains six glycosides previously undescribed in the genus Hippocrepis. Thus, fractions $n$-BFD 6 to $n$-BFD 12 , were further screened for their biological activity. As shown in Table $\mathrm{S} 1$, fractions $n-\mathrm{BFD}_{6}$ to $n$-BFD 9 had the best antioxidant and anti-elastase activities. The screening results indicate that the fractionation of $n$-BFD has increased the DPPH radical scavenging potential and the elastase inhibitory activity.

\subsection{Purification of the active fractions of $n-B F D$}

Since active fractions $n$-BFD $6^{-9}$ contained metabolites which were not unambiguously identified over the dereplication process, further purifications were performed using semipreparative and preparative HPLC. Fraction $n-\mathrm{BFD}_{12}$ was also purified by semi-preparative HPLC because it contains a non-identified tri-glycosylated flavonoid. All purified chemical structures were unambiguously assigned based on NMR and HR-ESI-MS data which afforded three undescribed glycosylated flavonoids $(\mathbf{1}-\mathbf{3})$ and twelve known compounds $(\mathbf{4}-\mathbf{1 5})$.

Compound 1 was obtained as yellowish-brown solid with a molecular formula of $\mathrm{C}_{33} \mathrm{H}_{40} \mathrm{O}_{20}$, deduced from its positive HR-ESI-MS analysis $\left(\mathrm{m} / z, 779.2020,[\mathrm{M}+\mathrm{Na}]^{+}\right)$. The UV spectrum showed the characteristic absorption of a flavonol skeleton at 210, 266 and 348 $\mathrm{nm}$. The ${ }^{1} \mathrm{H}$ and ${ }^{13} \mathrm{C}$ NMR spectra of $\mathbf{1}$ comprised resonances corresponding to aromatic and glycosidic protons and carbons. The ${ }^{1} \mathrm{H}$ NMR spectrum of $\mathbf{1}$ (Table 2) showed two doublets at $\delta_{\mathrm{H}} 6.52$ and 6.81 (each $\mathrm{H}, \mathrm{d}, J=2.1 \mathrm{~Hz}$ ), due to $\mathrm{H}-6$ and $\mathrm{H}-8$ in A-ring, as well as. two 
doublets at $\delta_{\mathrm{H}} 8.11$ and 6.92 (each $2 \mathrm{H}, \mathrm{d}, J=8.9 \mathrm{~Hz}$ ), due respectively to the protons $\mathrm{H}-2^{\prime}, 6^{\prime}$ and $\mathrm{H}-3^{\prime}, 5^{\prime}$ of a 4'-hydroxyphenyl moiety in B-ring. These protons were correlated in the HSQC spectrum with their aromatic carbon atoms at $\delta_{\mathrm{C}} 99.2,94.2,130.9$, and 114.7, respectively. Complete assignment of the remaining resonances of the aglycone in the ${ }^{13} \mathrm{C}$ NMR spectrum of $\mathbf{1}$ was achieved by analysis of the HSQC and HMBC data which confirmed the presence of kaempferol (3,5,7,4'-tetrahydroxy-flavone) (Xiao et al., 2006). A full list of the corresponding assignments is given in Table 2. Furthermore, three anomeric proton resonances corresponding to $O$-linked sugars were observed in the ${ }^{1} \mathrm{H}$ NMR spectrum as three doublets at $\delta_{\mathrm{H}} 5.37\left(J=7.3 \mathrm{~Hz}, \mathrm{H}-1^{\prime \prime}\right), 5.62\left(J=1.5 \mathrm{~Hz}, \mathrm{H}-1^{\prime \prime \prime}\right)$ and $4.64\left(J=7.7 \mathrm{~Hz}, \mathrm{H}-1^{\prime \prime \prime \prime}\right)$. The signals of their corresponding ${ }^{13} \mathrm{C}$ NMR carbons were at $\delta_{\mathrm{C}} 102.1\left(\mathrm{C}-1^{\prime \prime}\right), 98.1\left(\mathrm{C}-1^{\prime \prime \prime}\right)$ and $104.5\left(\mathrm{C}-1^{\prime \prime \prime \prime}\right)$, respectively. A methyl signal at $\delta_{\mathrm{H}} 1.29$ (d, $\left.J=5.4 \mathrm{~Hz}, \mathrm{H}-6^{\prime \prime \prime}\right)$ and $\delta_{\mathrm{C}} 16.8$ indicated a 6-desoxy-hexose, whereas signals for two hydroxymethylenes $\left[\delta_{\mathrm{H}} 3.54, \mathrm{dd}, J=\right.$ 12.0, 5.7 Hz, 3.73,dd, $J=12.0,2.3 \mathrm{~Hz}\left(\mathrm{H}-6^{\prime \prime}\right) ; \delta_{\mathrm{C}} 61.2\left(\mathrm{C}-6^{\prime \prime}\right)$ and $\delta_{\mathrm{H}} 3.75, \mathrm{dd}, J=12.0,4.7$ $\mathrm{Hz} / 3.88$,dd, $\left.J=12.0,1.5 \mathrm{~Hz}\left(\mathrm{H}-6^{\prime \prime \prime \prime}\right) ; 60.8\left(\mathrm{C}-6^{\prime \prime \prime}\right)\right]$ indicated two hexose moieties. Analysis of COSY correlations allowed us to assign complete spin systems of two $\beta$-D-glucopyranoses and an $\alpha$-L-rhamnopyranose (Ozden et al., 1998, Bock and Pedersen, 1983) (Table 2). The ${ }^{13} \mathrm{C}$ NMR data of each monosaccharide were attributed by analysis of HSQC spectra and indicated the presence of two terminal $\beta$-D-glucopyranoses and a 3 -substitued $\alpha$-L-rhamnopyranose $\left(\delta_{\mathrm{C}}\right.$ $\left.3^{\prime \prime \prime} 81.1\right)$. The relatively large ${ }^{3} J_{\mathrm{H}-1, \mathrm{H}-2}$ values of the glucoses $(7.3-7.7 \mathrm{~Hz})$ indicated a $\beta$ anomeric orientation for both glucopyranose units. The $\alpha$-configuration of rhamnose deduced from the small ${ }^{3} J_{\mathrm{H}-1, \mathrm{H}-2}$ value, was confirmed by the chemical shift of C-5 ( $\left.\delta \mathrm{C} 69.5\right)$ (Chang et al., 2007). The linkage sites of the monosaccharide units were determined by analysis of HMBC spectrum. The HMBC correlations between $\mathrm{H}-1 "{ }^{\prime \prime}\left(\delta_{\mathrm{H}} 5.37\right) / \mathrm{C}-3$ of the aglycone $\left(\delta_{\mathrm{C}}\right.$ 134.2) and H-1"' $\left(\delta_{\mathrm{H}} 5.62\right) / \mathrm{C}-7$ of the aglycone $\left(\delta_{\mathrm{C}} 161.9\right)$ indicated positions of sugars on the kaempferol, whereas correlation between $\mathrm{H}-1^{\prime \prime \prime \prime}\left(\delta_{\mathrm{H}} 4.64\right)$ and C-3"' $\left(\delta_{\mathrm{C}-3} 3^{\prime \prime \prime} 81.1\right)$ indicated that the second glucose unit was linked to C-3"' of the rhamnose unit. Therefore, the structure of $\mathbf{1}$ was elucidated as kaempferol-3- $O$ - $\beta$-D-glucopyranosyl-7- $O-\beta$-D-glucopyranosyl- $(1 \rightarrow 3)-\alpha-\mathrm{L}-$ rhamnopyranoside shown in Fig. 2.

Compound 2 was obtained as yellowish-brown solid with a molecular formula of $\mathrm{C}_{34} \mathrm{H}_{42} \mathrm{O}_{21}$, deduced from the positive HR-ESI-MS analysis $\left(m / z, 809.2108,[\mathrm{M}+\mathrm{Na}]^{+}\right)$and indicating an additional methoxy group by comparison with $\mathbf{1}$. The UV spectrum showed the characteristic absorption of flavonol at 204, 254 and $354 \mathrm{~nm}$. The ${ }^{1} \mathrm{H}$ and ${ }^{13} \mathrm{C}$ NMR spectra of $\mathbf{2}$ comprised resonances corresponding to aromatic and glycosidic protons and carbons, and 
one methoxy group. The A-ring of the flavonol was represented by two meta-coupled resonances at $\delta_{\mathrm{H}} 6.52\left(\mathrm{~d}, J=2.0 \mathrm{~Hz} ; \delta_{\mathrm{C}} 99.3\right)$ and $6.81\left(\mathrm{~d}, J=2.0 \mathrm{~Hz} ; \delta_{\mathrm{C}} 94.2\right)$, assigned to $\mathrm{H}-$ 6 and H-8, respectively. In the COSY and ${ }^{1} \mathrm{H}$ NMR spectra, a three protons ABX system was present at $\delta_{\mathrm{H}} 7.97\left(\mathrm{~d}, J=1.7 \mathrm{~Hz}, \mathrm{H}-2^{\prime}\right), 6.94\left(\mathrm{~d}, J=8.5 \mathrm{~Hz}, \mathrm{H}-5^{\prime}\right)$ and $7.65(\mathrm{dd}, J=8.5,1.7$ $\left.\mathrm{Hz}, \mathrm{H}-6^{\prime}\right)$, typical of a $3^{\prime}, 4^{\prime}$-disubstituted B-ring of a flavonoid nucleus. The location of the methoxy group was established at C-3' from the correlation observed in the HMBC spectrum from $\delta_{\mathrm{H}} 3.97\left(3 \mathrm{H}, \mathrm{s} ; \delta_{\mathrm{C}} 55.4\right)$ to $\mathrm{C}-3^{\prime}\left(\delta_{\mathrm{C}} 147.1\right)$. Complete assignment of the remaining resonances of the aglycone in the ${ }^{13} \mathrm{C}$ NMR spectrum of 2 was achieved by analysis of the HSQC and HMBC data, which confirmed the presence of isorhamnetin $\left(3,5,7,4^{\prime}-\right.$ tetrahydroxy-3'-methoxyflavone) (Roesch et al., 2004). A full list of the corresponding assignments is given in Table 2. Analysis of 2D NMR experiments of $\mathbf{2}$ and comparison of its ${ }^{1} \mathrm{H}$ and ${ }^{13} \mathrm{C}$ NMR data with those of $\mathbf{1}$ showed that $\mathbf{2}$ contained also three sugar units, two of them were elucidated as above as $\beta$-D-glucopyranoses and one was identified as a terminal $\alpha$ L-rhamnopyranose (Ozden et al., 1998) (Table 2). The site of glycosylations was established at the 3 and 7 position of isorhamnetin, as demonstrated by the HMBC spectrum showing correlations from H-1"' $\left(\delta_{\mathrm{H}} 5.63\right) / \mathrm{C}-7\left(\delta_{\mathrm{C}} 162.0\right), \mathrm{H}-1$ " $\left(\delta_{\mathrm{H}} 5.51\right) / \mathrm{C}-3\left(\delta_{\mathrm{C}} 134.2\right)$ and H-1"'" $\left(\delta_{\mathrm{H}}\right.$ $4.64) / \mathrm{C}-3^{\prime \prime \prime}\left(\delta_{\mathrm{C}} 81.1\right)$. Thus, the structure of compound 2 was concluded to be isorhamnetin-3$O$ - $\beta$-D-glucopyranosyl-7- $O-\beta$-D-glucopyranosyl-( $1 \rightarrow 3$ )- $\alpha$-L-rhamnopyranoside (Fig. 2).

Compound 3 was obtained as yellowish-brown solid. Its positive HR-ESI-MS spectra showed a pseudomolecular ion $[\mathrm{M}+\mathrm{Na}]^{+}$at $\mathrm{m} / z$ 779.2007, indicating a molecular formula of $\mathrm{C}_{33} \mathrm{H}_{40} \mathrm{O}_{20}$. The UV spectrum showed the characteristic absorption of flavonol at 208, 256 and $348 \mathrm{~nm}$. The ${ }^{1} \mathrm{H}$ and ${ }^{13} \mathrm{C}$ NMR spectroscopic data of compound 3 showed two distinct parts, the aglycone and three sugars. The ${ }^{1} \mathrm{H}$ and ${ }^{13} \mathrm{C}$ NMR spectra showed characteristic signals of quercetin $\left(3,5,7,3^{\prime}, 4^{\prime}\right.$-pentahydroxy-flavone) at $\delta_{\mathrm{H}} 6.46\left(\mathrm{~d}, J=2.1 \mathrm{~Hz}, \mathrm{H}-6 ; \delta_{\mathrm{C}} 99.9\right), 6.82(\mathrm{~d}, J$ $\left.=2.1 \mathrm{~Hz}, \mathrm{H}-8 ; \delta_{\mathrm{C}} 94.8\right), 7.67\left(\mathrm{~d}, J=2.1 \mathrm{~Hz}, \mathrm{H}-2^{\prime} ; \delta_{\mathrm{C}} 117.2\right), 7.18$ (d, $J=9.3 \mathrm{~Hz}, \mathrm{H}-5^{\prime} ; \delta_{\mathrm{C}}$ 116.7) and 7.67 (dd, $J=9.1,2.2 \mathrm{~Hz}, \mathrm{H}-6^{\prime} ; \delta_{\mathrm{C}}$ 121.6) (Ibrahim et al., 2016) (Table 2). The ${ }^{1} \mathrm{H}$ and ${ }^{13} \mathrm{C}$ NMR spectra showed three anomeric signals at $\delta_{\mathrm{H}} 5.51\left(\mathrm{~d}, J=7.1 \mathrm{~Hz}, \mathrm{H}-1 " ; \delta_{\mathrm{C}}\right.$ 101.2), 5.57 (d, $\left.J=1.4 \mathrm{~Hz}, \mathrm{H}-1^{\prime \prime \prime} ; \delta_{\mathrm{C}} 98.9\right)$ and 5.43 (d, $\left.J=1.4 \mathrm{~Hz}, \mathrm{H}-1^{\prime \prime \prime \prime} ; \delta_{\mathrm{C}} 99.6\right)$, in addition to two methyl signals $\left(\delta_{\mathrm{H}} 1.13,6 \mathrm{H}, \mathrm{d}, J=6.1 \mathrm{~Hz}, \mathrm{H}-6^{\prime \prime \prime}\right.$ and H-6"'"; $\left.\delta_{\mathrm{C}} 18.4\right)$. The analysis of COSY, HSQC and HMBC experiments led to the identification of three terminal sugar units: two $\alpha$-L-rhamnopyranoses and one $\beta$-D-glucopyranose (Ozden et al., 1998) (Table 2). The HMBC correlations between H-1"/C-3 ( $\left.\delta_{\mathrm{C}} 134.6\right), \mathrm{H}-1^{\prime \prime \prime} / \mathrm{C}-7\left(\delta_{\mathrm{C}} 162.2\right)$, and H-1"'"/C- 
$4^{\prime}\left(\delta_{\mathrm{C}} 147.1\right)$ indicated the glycosylation sites. Therefore, the structure of $\mathbf{3}$ was elucidated as quercetin-3-O- $\beta$-D-glucopyranosyl-7,4'-di- $O$ - $\alpha$-L-rhamnopyranoside (Fig. 2).

Compounds 4-6, 11, and 13-15 already identified during the dereplication process were also isolated in addition to isorhamnetin-3-O- $\beta$-D-glucopyranosyl-7- $O-\alpha-\mathrm{L}-$ rhamnopyranoside (7) (Roesch et al., 2004), kaempferol-3-O- $\alpha$-L-rhamnopyranosyl-(1 $\rightarrow 6)-\beta$ D-glucopyranoside (8) (Kazuma et al., 2003), quercetin-3-O- $\alpha$-L-rhamnopyranosyl-(1 $\rightarrow 6)-\beta$ D-glucopyranoside (9) (Ibrahim et al., 2016), quercetin (10) (Ibrahim et al., 2016), and quercetin-7-O- $\alpha$-L-rhamnopyranoside (12) (Ibrahim et al., 2016) (Fig. 2 and S2). The structural assignments of these compounds were made by ESI-MS, 1D and 2D-NMR analysis.

\subsection{Biological assays on compounds}

Isolated compounds were evaluated for their antioxidant potential using DPPH and hydroxyl radicals scavenging assays, CUPRAC assay, and for their tyrosinase and elastase inhibitory properties. Some compounds have not been screened for these five assays due to poor yields. For these compounds, their biological potential was discussed based on literature data when possible. As summarized in Table 1, compounds 6, 9 and 12 exhibited the best antioxidant activities. Compounds 6 and 9 (Arimboor et al., 2012) exhibited the highest antioxidant potential in DPPH, hydroxyl radicals scavenging, and CUPRAC tests (6: IC $_{50} 44.4$ , 31.1 and $23.3 \mu \mathrm{M}$, respectively; 9: $\mathrm{IC}_{50} 28.8,145.8$ and $13.9 \mu \mathrm{M}$, respectively). Compound 12 exhibited also good activities in DPPH and CUPRAC tests $\left(\mathrm{IC}_{50} 81.2\right.$ and $14.5 \mu \mathrm{M}$, respectively). Compound $\mathbf{5}$ showed moderate activities in hydroxyl scavenging and CUPRAC assays (IC 50110.2 and $47.9 \mu \mathrm{M}$, respectively) and compound 11 (Zhou et al., 2015) exhibited moderate activities in DPPH and CUPRAC tests ( $\mathrm{IC}_{50} 83$ and $72.8 \mu \mathrm{M}$, respectively). Compound 8 showed moderate activity only in CUPRAC assay ( $\mathrm{IC}_{50} 57.7 \mu \mathrm{M}$ ), whereas compounds 1-4, 7 and 13 (Kiem et al., 2012) exhibited low antioxidant activities. The kaempferol glycosides 5, $\mathbf{8}$ and $\mathbf{1 1}$ were more active in CUPRAC assay than the isorhamnetin glycosides $\mathbf{2}$ and 7. In most cases, quercetin derivatives exhibited higher antioxidant activity than kaempferol and isorhamnetin due to the presence of two free $\mathrm{OH}$ group at positions 3' and 4' of the B-ring (Prochazkova et al., 2011). Our results confirm this relationship since the most active compounds 6, 9 and $\mathbf{1 2}$ are quercetin-type flavonoids. Moreover, the results indicated also that compounds 5 and 6 (having two sugars in positions 3 and 7 of the aglycone) showed better activity in antioxidant assays when compared to compounds $\mathbf{3}$ and $\mathbf{4}$ 
(having three sugars in positions 3,7 and 4' of the aglycone), due to glycosylation at 4' position in $\mathbf{3}$ and $\mathbf{4}$.

Concerning the anti-tyrosinase tests, only compound 14 (phenylethylglucoside) (Luyen et al., 2017) exhibited a significant activity ( $\mathrm{IC}_{50} 63.4 \mu \mathrm{M}$ ). It is more active than its analog compound 13 (benzylglucoside). This suggested another structure-activity relationship based on chain length that would increase anti-tyrosinase activity. Only compound $\mathbf{8}$ showed a moderate elastase inhibitory activity ( $\mathrm{IC}_{50} 86.1 \mu \mathrm{M}$ ). The inhibitory capacity of compounds 8 and 12 is greater than that of compound 9 and 11, respectively, but lower than that of quercetin (10) found in the literature (Sartor et al., 2002). These results suggest that sugars attached to positions 3 or 7 of the aglycone decrease anti-elastase activity.

\section{Conclusions}

Thirty-two secondary metabolites including flavonoids, phenolic acids, coronillins and glycosides derivatives, were identified in a flower extract of Hippocrepis emerus. Three new flavonoids were identified, and seventeen compounds are reported here for the first time in the genus Hippocrepis. ${ }^{13} \mathrm{C}$ NMR-based dereplication combined to bioactivity-guided fractionation allowed to rapidly determine the global chemical composition of the extract and to orientate purification and biological screening of the most interesting fractions.

On a chemical standpoint, the originality in structures of the characterized flavonoids lies in different position of the osidic part. The tri-substituted flavonoids $\mathbf{3}$ and $\mathbf{4}$ are characteristic of this species. Compound 4 has been previously mentioned in $H$. emerus flowers on the base of UV analysis and acid hydrolysis (Harborne and Boardley, 1983). This study confirms the presence of $\mathbf{4}$ in this species and complete and unambiguous ${ }^{1} \mathrm{H}$ and ${ }^{13} \mathrm{C}$ NMR chemical shift assignments for this compound have been established by means of 1Dand 2D-NMR spectroscopic experiments (Table 2). Among the identified compounds, quercetin-type flavonoids 6, 9 and 12 showed a powerful antioxidant activity and phenylethyl$\beta$-D-glucopyranoside (14) showed a mushroom tyrosinase inhibition. These tests have highlighted the antioxidant activity of glycosylated flavonoids and more particularly quercetin-type flavonoids with two maximum sugars. The EAF, $n$-BF and the bi-glycosylated flavonoids of quercetin type identified from $H$. emerus could be valued in the dermo-cosmetic field for their very interesting antioxidant activities.

\section{Experimental}




\subsection{General experimental procedures}

Optical rotations of pure compounds were measured in $\mathrm{CH}_{3} \mathrm{OH}$ using a Perkin-Elmer 341 Polarimeter (589 nm, $\left.20{ }^{\circ} \mathrm{C}\right) .{ }^{1} \mathrm{H}-,{ }^{13} \mathrm{C}-\mathrm{NMR}$ and 2D-NMR measurements were recorded at $298 \mathrm{~K}$ in $\mathrm{CH}_{3} \mathrm{OH}-d_{4}$ or DMSO- $d_{6}$ on a Bruker Avance AVIII-600 spectrometer (Karlsruhe, Germany) $\left({ }^{1} \mathrm{H}\right.$ at $600 \mathrm{MHz}$ and ${ }^{13} \mathrm{C}$ at $\left.150 \mathrm{MHz}\right)$ equipped with a $5 \mathrm{~mm}$ TCI cryoprobe. 2DNMR experiments were performed using standard Bruker microprograms (TopSpin 3.2 software). HR-ESI-MS experiments were realized using a Micromass Q-TOF micro instrument (Manchester, UK). Mass spectra were recorded in the positive-ion mode in the range $m / z 100-2000$, with a mass resolution of 20000 and an acceleration voltage of $0.7 \mathrm{kV}$. Preparative HPLC was performed on Armen Instrument apparatus equipped with an AP 250 pump and a Knauer (Merck) detector UV K-2501. Semi-preparative HPLC was realized on a Dionex apparatus equipped with an ASI-100 automated sample injector, a STH 585 column oven, a P580 pump, a diode array detector UVD 340S and the Chromeleon ${ }^{\circledR}$ software version 6.8. Analytical HPLC experiments were performed using a Thermofisher Ultimate 3000 (Thermo Fischer Scientific, Villebon sur Yvette, France), equipped with a 4 ways pump LPG 3400 SD, an automatic injector WPS 3000 SL, a UV/visible diode array detector 3000 and the Chromeleon ${ }^{\circledR}$ software version 6.8. A manually packed $\mathrm{C}_{18}$ column (LiChrospher, 20 x $5 \mathrm{~cm}$, $12 \mu$ ) was used for preparative HPLC. The mobile phase consisted of $\mathrm{H}_{2} \mathrm{O}$ with TFA $(0.0025 \%)$ and $\mathrm{CH}_{3} \mathrm{CN}$ with a flow rate of $100 \mathrm{~mL} / \mathrm{min}$ and the chromatograms were monitored at 205, 254, 300 and $360 \mathrm{~nm}$. A prepacked $\mathrm{C}_{18}$ column (Phenomenex Luna, $250 \times 15 \mathrm{~mm}, 5 \mu$ ) was exploited for semi-preparative HPLC. The mobile phase was composed of $\mathrm{H}_{2} \mathrm{O}$ with TFA $(0.0025 \%)$ and $\mathrm{CH}_{3} \mathrm{CN}$ with a flow rate of $6 \mathrm{~mL} / \mathrm{min}$ and the chromatograms were monitored at 205, 254, 300 and $360 \mathrm{~nm}$. A prepacked $\mathrm{C}_{18}$ column Uptisphere Strategy $\mathrm{C}_{18}$ (Interchim, $4.6 \times 250 \mathrm{~mm}, 5 \mu$ ) was used for analytical HPLC and the mobile phase consisted of $\mathrm{H}_{2} \mathrm{O}$ with TFA $\left(0.0025 \%\right.$ v/v) and $\mathrm{CH}_{3} \mathrm{CN}$. A gradient elution method was applied from $5 \%$ to $80 \%$ of $\mathrm{CH}_{3} \mathrm{CN}$ in $30 \mathrm{~min}$ with a flow rate of $1 \mathrm{~mL} / \mathrm{min}$ and the chromatograms were monitored at 205, 254, 300 and $360 \mathrm{~nm}$. CC was carried out on HP20 resin (Sigma Aldrich). Thin-layer chromatography (TLC) was carried out on silica gel 60 $\mathrm{F}_{254}$ pre-coated aluminum plates $\left(0.2 \mathrm{~mm}\right.$, Merck), using the system $\mathrm{CHCl}_{3} / \mathrm{MeOH} / \mathrm{H}_{2} \mathrm{O}$ $(70 / 30 / 5, v / v / v)$ as the mobile phase. The spots were visualized under UV light (254 and 366 $\mathrm{nm}$ ) using high-performance thin-layer chromatography (HPTLC, CAMAG TLC Visualizer 2) and sprayed with $50 \% \mathrm{H}_{2} \mathrm{SO}_{4}$ followed by heating. A FLUOstar Omega spectrophotometer (BMG LABTECH) was used for measuring the absorbance of antioxidant and anti-tyrosinase 
assays. An Infinite F200 PRO spectrofluorimeter (Tecan, Lyon, France) was used for measuring the fluorescence of anti-elastase assay.

\subsection{Plant material}

The flowers of Hippocrepis emerus (L.) Lassen (=Coronilla emerus L.) (Fabaceae) was collected in Cormontreuil (Northeastern of France: $49^{\circ} 2167^{\prime} \mathrm{N}, 4^{\circ} 05^{\prime} \mathrm{E}$ ) in April 2016 , authenticated by Dr. Abdulmagid Alabdul Magid and dried at room temperature. A voucher specimen was deposited at the Herbarium of the Botanic laboratory-Faculty of Pharmacy, University of Reims Champagne-Ardenne, under the sheet reference (MA-HE-2016-04).

\subsection{Extraction and isolation}

The dried and powdered H. emerus flowers (300 g) was macerated in $80 \% \mathrm{MeOH}(3 \mathrm{x}$ $3 \mathrm{~L}, 24 \mathrm{~h}$ ) at room temperature, followed by concentration at $40{ }^{\circ} \mathrm{C}$ under vacuum in order to evaporate the methanol and obtain an aqueous solution. An aliquot of the aqueous solution $(100 \mathrm{~mL})$ was evaporated to dryness to obtain the $80 \% \mathrm{MeOH}$ extract (HEM) $(2.9 \mathrm{~g})$. The aqueous solution ( $1 \mathrm{~L})$ was extracted successively with dichloromethane (3 x $750 \mathrm{~mL})$, ethyl acetate $(3 \times 750 \mathrm{~mL})$ and $n$-butanol $(3 \times 750 \mathrm{~mL})$, then dried under reduced pressure to yield $\operatorname{DCMF}(2.8 \mathrm{~g}), \operatorname{EAF}$ ( $2.4 \mathrm{~g}$ ), and $n$-BF (11.4 g), respectively and a water-soluble part ( $6.9 \mathrm{~g})$. The $n$-BF fraction was dissolved in $1 \mathrm{~L} \mathrm{H}_{2} \mathrm{O}$ and then subjected to a Diaion HP-20 macroporous resin column $(5.5 \times 26 \mathrm{~cm})$, eluting sequentially with a mixture of $\mathrm{MeOH}-\mathrm{H}_{2} \mathrm{O}$ $(0 \%, 25 \%, 50 \%, 75 \%$ and $100 \% \mathrm{MeOH}, 1.8 \mathrm{~L}$ each) to provide five fractions $n$-BFA $-n$ BFE, respectively.

\subsubsection{Centrifugal partition chromatography}

Centrifugal partition chromatography (CPC) experiments were carried out using a labscale FCPE300® column of 303 mL capacity (Rousselet Robatel Kromaton, Annonay, France) containing 7 circular partition disks and engraved with a total of 231 partition twincells $(\approx 1 \mathrm{~mL}$ per twin cell). The liquid phases were pumped by a KNAUER Preparative 1800 V7115 pump (Berlin, Germany). The column was coupled on-line with a UVD 170 S detector set at 210, 254, 280 and $366 \mathrm{~nm}$ (Dionex, Sunnivale, CA, USA). Fractions of $20 \mathrm{~mL}$ were collected by a Pharmacia Superfrac collector (Uppsala, Sweden). The solvent system was $\mathrm{MtBE} / \mathrm{CH}_{3} \mathrm{CN} /$ water in the ratio 3/3/4 (v/v/v). The column rotation speed was set at $1200 \mathrm{rpm}$ and the flow rate at $20 \mathrm{~mL} / \mathrm{min}$. 
EAF and $n$-BFD were subjected independently to CPC; each one was dissolved in 25 $\mathrm{mL}$ of a mixture of both lower phase $(20 \mathrm{~mL})$ and upper phase $(5 \mathrm{~mL})$. For the separation of EAF (1.6 g injected), the upper phase of the biphasic solvent system was pumped for $100 \mathrm{~min}$ in the ascending mode. Then the column was extruded by pumping the organic phase in the descending mode still at $20 \mathrm{~mL} / \mathrm{min}$. Fractions of $20 \mathrm{~mL}$ were collected over the whole experiment. All fractions were analyzed by TLC and HPLC and then pooled, giving fractions $\mathrm{EAF}_{1-23 .}$

For the separation of $n$-BFD (1.45 g), the CPC method was identical, except for the pumping time of the upper phase which was $200 \mathrm{~min}$. All fractions were analyzed by TLC and HPLC and then pooled, giving fractions $n$-BFD $1-13$.

\subsubsection{NMR analyses and dereplication of the metabolites}

As a first step in this developed ${ }^{13} \mathrm{C}$ NMR-based dereplication method (Hubert et al., 2014), structures and names of metabolites already described in the genus Hippocrepis $(\mathrm{n}=68)$ were collected from the reports available in the literature. The predicted ${ }^{13} \mathrm{C}$ NMR chemical shifts of each one was then stored into a local database already comprising 2500 structures of natural compounds (NMR Workbook Suite 2012, ACD/Labs, Ontario, Canada). In the second step, all CPC fractions were dried under vacuum and an aliquot (up to $20 \mathrm{mg}$ when possible) was dissolved in $600 \mu \mathrm{L}$ of DMSO- $d_{6}$ and analyzed by ${ }^{13} \mathrm{C}$ NMR. ${ }^{13} \mathrm{C}$ NMR spectra were acquired at $150.91 \mathrm{MHz}$. A standard zgpg pulse sequence was used with an acquisition time of $0.9 \mathrm{~s}$ and a relaxation delay of $3 \mathrm{~s}$. For each sample, 1024 scans were added to obtain a satisfactory signal-to-noise ratio. The spectral width was $240 \mathrm{ppm}$ and the receiver gain was set to the highest possible value. Spectra were then manually phased, baseline corrected using the TOPSPIN3.2 software (Bruker), and calibrated on the central resonance of DMSO$d_{6}(\delta 39.8 \mathrm{ppm})$.

The last step consisted in the binning of all ${ }^{13} \mathrm{C}$ NMR signals followed by the visualization of the whole dataset as a heat map. For this purpose, the absolute intensities of all ${ }^{13} \mathrm{C}$ NMR signals detected in the spectra of the fraction series were automatically collected and each resulting peak list was stored as a text file. The binning step was performed by using a locally developed computer script written in Python language. Its principle was to divide the ${ }^{13} \mathrm{C}$ spectral width (from 0 to $240 \mathrm{ppm}$ ) into regular chemical shift windows $(\Delta \delta=0.2 \mathrm{ppm})$, and to associate the absolute intensity of each peak to the corresponding bin. The resulting table was imported into the PermutMatrix version 1.9.3 software (LIRMM, 
Montpellier, France) and submitted to Hierarchical Clustering Analysis (HCA) for data visualization. Then the chemical shifts clusters regrouped with the HCA were compared to a database to identify the compounds. In order to confirm the structures of the identified compounds, additional 1D and 2D NMR experiments $\left({ }^{1} \mathrm{H}\right.$ NMR, HSQC, HMBC, and ${ }^{1} \mathrm{H}-{ }^{1} \mathrm{H}-$ COSY) were registered and analyzed.

\subsubsection{HPLC purification of $n$-BFD}

Fractions $n$-BFD 6-7 were subjected to preparative HPLC using the gradient system (15$\left.25 \% \mathrm{CH}_{3} \mathrm{CN}, 45 \mathrm{~min}\right)$ to yield compounds $13\left(\mathrm{t}_{\mathrm{R}}=7.7 \mathrm{~min}, 15 \mathrm{mg}\right), 6\left(\mathrm{t}_{\mathrm{R}}=8.4 \mathrm{~min}, 38 \mathrm{mg}\right), 9$ $\left(\mathrm{t}_{\mathrm{R}}=12.8 \mathrm{~min}, 15 \mathrm{mg}\right)$ and $\mathbf{8}\left(\mathrm{t}_{\mathrm{R}}=16.2 \mathrm{~min}, 36 \mathrm{mg}\right)$. Subfraction 17 was purified by semi-prep. HPLC with isocratic system $\left(17 \% \mathrm{CH}_{3} \mathrm{CN}, 20 \mathrm{~min}\right)$ to yield compound $5\left(\mathrm{t}_{\mathrm{R}}=9.8 \mathrm{~min}, 8 \mathrm{mg}\right.$ ), and a mixture of 14 and $15\left(t_{R}=14.5 \mathrm{~min}, 4 \mathrm{mg}\right)$. Subfraction 27-28 was purified by semi-prep. HPLC with gradient system (30-35\% $\left.\mathrm{CH}_{3} \mathrm{CN}, 20 \mathrm{~min}\right)$ to yield compounds $12\left(\mathrm{t}_{\mathrm{R}}=7.3 \mathrm{~min}, 4\right.$ $\mathrm{mg}), 11\left(\mathrm{t}_{\mathrm{R}}=10.2 \mathrm{~min}, 7 \mathrm{mg}\right)$, and $10\left(\mathrm{t}_{\mathrm{R}}=12.4 \mathrm{~min}, 3 \mathrm{mg}\right)$. Fractions $n$-BFD $\mathrm{B}_{8-9}$ were purified by semi-prep. HPLC with gradient system $\left(17-22 \% \mathrm{CH}_{3} \mathrm{CN}, 15 \mathrm{~min}\right)$ to yield compound 7 $\left(\mathrm{t}_{\mathrm{R}}=9.0 \mathrm{~min}, 12 \mathrm{mg}\right)$. Fraction $n-\mathrm{BFD}_{12}$ was purified by preparative HPLC with gradient system (17-23\% $\left.\mathrm{CH}_{3} \mathrm{CN}, 45 \mathrm{~min}\right)$ to yield compounds $3\left(\mathrm{t}_{\mathrm{R}}=5.5 \mathrm{~min}, 20 \mathrm{mg}\right)$ and $\mathbf{4}:\left(\mathrm{t}_{\mathrm{R}}=6.5\right.$ min, $55 \mathrm{mg}$ ). Subfraction 33-35 was purified by semi-prep. HPLC with isocratic system (17\% $\left.\mathrm{CH}_{3} \mathrm{CN}, 20 \mathrm{~min}\right)$ to yield compounds $1\left(t_{\mathrm{R}}=11.2 \mathrm{~min}, 0.6 \mathrm{mg}\right)$ and $2\left(\mathrm{t}_{\mathrm{R}}=11.9 \mathrm{~min}, 2 \mathrm{mg}\right)$.

\subsection{Kaempferol-3-O- $\beta$-D-glucopyranosyl-7-O- $\beta$-D-glucopyranosyl-( $1 \rightarrow 3)-\alpha-L-$} rhamnopyranoside (1)

Yellowish-brown solid; $[\alpha]_{\mathrm{D}}-8.8\left(c\right.$ 0.05, MeOH); UV $(\mathrm{MeOH}) \lambda_{\max }(\log \varepsilon) 210$ (4.22), 266 (4.03) and 348 (3.93); ${ }^{1} \mathrm{H}$ and ${ }^{13} \mathrm{C}$ NMR data, see Table 2; HR-ESI-MS (positiveion mode) $m / z: 779.2020[\mathrm{M}+\mathrm{Na}]^{+}\left(\right.$calculated for $\left.\mathrm{C}_{33} \mathrm{H}_{40} \mathrm{O}_{20} \mathrm{Na}, 779.2011\right)$.

\subsection{Isorhamnetin-3-O- $\beta$-D-glucopyranosyl-7-O- $\beta$-D-glucopyranosyl- $(1 \rightarrow 3)-\alpha-L-$}

rhamnopyranoside (2)

Yellowish-brown solid; $[\alpha]_{\mathrm{D}}-7.8$ (c $\left.0.06, \mathrm{MeOH}\right) ; \mathrm{UV}(\mathrm{MeOH}) \lambda_{\max }(\log \varepsilon) 204$ (4.16), 254 (3.86) and 354 (3.74); ${ }^{1} \mathrm{H}$ and ${ }^{13} \mathrm{C}$ NMR data, see Table 2; HR-ESI-MS (positiveion mode) $m / z: 809.2108[\mathrm{M}+\mathrm{Na}]^{+}$(calculated for $\mathrm{C}_{34} \mathrm{H}_{42} \mathrm{O}_{21} \mathrm{Na}, 809.2116$ ).

\subsection{Quercetin-3-O- $\beta$-D-glucopyranosyl-7,4'-di-O- $\alpha$-L-rhamnopyranoside (3)}


Yellowish-brown solid; $[\alpha]_{\mathrm{D}}-7.0(c \quad 0.58, \mathrm{MeOH}) ; \mathrm{UV}(\mathrm{MeOH}) \lambda_{\max }(\log \varepsilon) 208$ (4.34), 256 (4.13) and 348 (4.01); ${ }^{1} \mathrm{H}$ and ${ }^{13} \mathrm{C}$ NMR data, see Table 2; HR-ESI-MS (positiveion mode) $m / z: 779.2007[\mathrm{M}+\mathrm{Na}]^{+}\left(\right.$calculated for $\mathrm{C}_{33} \mathrm{H}_{40} \mathrm{O}_{20} \mathrm{Na}, 779.2011$ ).

\subsection{Antioxidant bioassay procedures}

\subsubsection{DPPH radical scavenging activity}

Extracts, fractions and compounds 1-7, 10, 12 and 13 were tested for their DPPH radical scavenging activity. The free radical scavenging capacity was determined by using the stable 1,1-diphenyl-2-picrylhydrazyl (DPPH) free radical (Sientzoff et al., 2015). Briefly, 5 $\mu \mathrm{L}$ of different concentrations of the samples (dissolved in $\mathrm{H}_{2} \mathrm{O} / \mathrm{DMSO} 9 / 1$, v/v) were added to $95 \mu \mathrm{L}$ of a DPPH solution $\left(158 \mu \mathrm{M}\right.$, dissolved in $\mathrm{EtOH} / \mathrm{H}_{2} \mathrm{O}(1 / 1, \mathrm{v} / \mathrm{v})$ freshly prepared. The reaction proceeded for $30 \mathrm{~min}$ at $37{ }^{\circ} \mathrm{C}$ on a 96 -well microplate and the absorbance was then read at $515 \mathrm{~nm}$. The DPPH inhibition percentage was calculated as followed: \% inhibition $\left[\left(\mathrm{Ab}_{\text {control }}-\mathrm{Ab}_{\text {sample }}\right) / \mathrm{A} b_{\text {control }}\right] \times 100$. A DPPH solution in EtOH $50 \%$ was used as a control. The curve of the \% scavenging activity against the concentration of sample was prepared by MSExcel based program to obtain the $\mathrm{IC}_{50}$. Samples were prepared at concentrations of 200,100, 50, 25, 12.5 and $6.25 \mu \mathrm{g} / \mathrm{mL}$. Ascorbic acid and quercetin were used as positive controls. All the tests were conducted in triplicate for each concentration examined.

\subsubsection{Hydroxyl radical scavenging activity}

Extracts, fractions and compounds 2, 4-6, 8, 10, 11 and 13 were tested for their hydroxyl radical scavenging activity. Hydroxyl radical scavenger ability was measured according to a literature procedure (Wang et al., 2007) with a few modifications. Hydroxyl radical was generated from Fenton reaction between $1.5 \mathrm{mM} \mathrm{FeSO}_{4}$ and $6 \mathrm{mM} \mathrm{H}_{2} \mathrm{O}_{2},(10: 7$, $\mathrm{v} / \mathrm{v}$ ) at $37{ }^{\circ} \mathrm{C}$ for $30 \mathrm{~min}$ before the assay and detected by their ability to hydroxylate salicylate. The reaction mixture $(300 \mu \mathrm{L})$ contained $100 \mu \mathrm{L} \mathrm{FeSO}_{4}(1.5 \mathrm{mM}), 70 \mu \mathrm{L} \mathrm{H}_{2} \mathrm{O}_{2}(6$ $\mathrm{mM}$, freshly prepared, $30 \mu \mathrm{L}$ sodium salicylate $(20 \mathrm{mM})$ and $100 \mu \mathrm{L}$ of varying concentrations of samples $(1330,665,332.5,166.25,83.12$ and $41.56 \mu \mathrm{g} / \mathrm{mL})$ dissolved in $\mathrm{H}_{2} \mathrm{O} / \mathrm{DMSO}(9 / 1, \mathrm{v} / \mathrm{v})$. After incubation for $1 \mathrm{~h}$ at $37{ }^{\circ} \mathrm{C}$, the absorbance of the hydroxylated salicylate complex was measured at $562 \mathrm{~nm}$. Ascorbic acid and quercetin were used as positive controls. The scavenging activity of hydroxyl radical effect was calculated as follows: $\left[1-\left(A_{1}-A_{2}\right) / A_{0}\right] \times 100$, where $A_{0}$ is absorbance of the control (without sample), $A_{1}$ 
is absorbance in the presence of the sample and $\mathrm{A}_{2}$ is absorbance without sodium salicylate. All the tests were conducted in triplicate and $\mathrm{IC}_{50}$ was determined by interpolation of concentration \% inhibition curve obtained by MSExcel based program.

\subsubsection{Power cupric ion reducing (CUPRAC)}

Extracts, fractions and compounds 1-12 were tested for their power cupric ion reducing. The cupric ion reducing activity (CUPRAC) was determined according to a literature method (Ceylan et al., 2016) with a few modifications. Samples were prepared at concentrations of $572,286,143,71.5,35.75,17.87$ and $8.94 \mu \mathrm{g} / \mathrm{mL}$ and dissolved in $\mathrm{H}_{2} \mathrm{O} / \mathrm{DMSO}(9 / 1, \mathrm{v} / \mathrm{v}) .45 \mu \mathrm{L}$ of each concentration were added to premixed reaction mixture containing $\mathrm{CuCl}_{2}(90 \mu \mathrm{L}, 10 \mathrm{mM})$, neocuproine freshly prepared $(90 \mu \mathrm{L}, 7.5 \mathrm{mM}$, dissolved in distilled water and ethanol in proportion 8/2, v/v) and $\mathrm{NH}_{4} \mathrm{Ac}$ buffer $(90 \mu \mathrm{L}, 1 \mathrm{M}, \mathrm{pH} 7.0$ ). Similarly, a blank was prepared by adding sample solution $(45 \mu \mathrm{L})$ to premixed reaction mixture $(270 \mu \mathrm{L})$ without $\mathrm{CuCl}_{2}$. The reaction proceeded for $30 \mathrm{~min}$ at room temperature on a 96-well microplate and the absorbance was then read at $450 \mathrm{~nm}$. Ascorbic acid, quercetin and trolox were used as positive controls. The power cupric ion reducing was calculated as follows: $\left[1-A_{0} /\left(A_{1}-A_{2}\right)\right] \times 100$, where $A_{0}$ is absorbance of the control (without sample), $A_{1}$ is absorbance in the presence of the sample and $A_{2}$ is absorbance of the blank. All the tests were conducted in triplicate and $\mathrm{IC}_{50}$ were determined by interpolation of concentration $\%$ inhibition curve obtained by MSExcel based program.

\subsection{Tyrosinase enzyme assay}

Extracts, fractions and compounds 2, 4-6, 11 and 13 were tested for their ability to inhibit tyrosinase. The tyrosinase inhibitory activity was determined according to the method described previously (Lehbili et al., 2018) with a few modifications. Briefly, L-DOPA was used as the substrate in this experiment. Samples were prepared at concentrations of 1330, $665,332.5,166.25$ and $83.12 \mu \mathrm{g} / \mathrm{mL}$ and dissolved in phosphate buffer solution (PBS, 20 mM, pH 6.8) and DMSO in proportion 9/1 (v/v). $100 \mu \mathrm{L}$ of each concentration were added to a 96-well microplate and then $100 \mu \mathrm{L}$ of $135 \mathrm{U} / \mathrm{mL}$ fungal tyrosinase in PBS were added. After pre-incubation at room temperature for $10 \mathrm{~min}$ in the dark, $100 \mu \mathrm{L}$ of L-DOPA $(0.5 \mathrm{mM}$ in PBS) were added. The reaction mixture was incubated for another $5 \mathrm{~min}$ at room temperature. The amount of dopachrome in the mixture was determined by the measurement of the absorbance of each well at $475 \mathrm{~nm}$. Kojic acid was used as a positive control. The 
inhibitory percentage of tyrosinase was calculated according to the following equation: \% inhibition $=\{[(\mathrm{A}-\mathrm{B})-(\mathrm{C}-\mathrm{D})] /(\mathrm{A}-\mathrm{B})\} \times 100$, where $\mathrm{A}$ is absorbance without sample, $\mathrm{B}$ is absorbance without sample and tyrosinase, $\mathrm{C}$ is absorbance with sample, and D is absorbance with sample and without tyrosinase. All the tests were conducted in triplicate. $\mathrm{IC}_{50}$ were determined by interpolation of concentration $\%$ inhibition curve obtained by MSExcel based program.

\subsection{Elastase enzyme assay}

Extracts, fractions and compounds 2-8 and 11-13 were tested for their ability to inhibit elastase. Elastase inhibition measurement was carried out using Human Leukocyte Elastase (HLE) (Merck Biosciences). Tests were performed in pre-coated 96-well microplates with 1\% Serum Albumin Bovine. HLE $(0.8 \mu \mathrm{M})$ was incubated for $1 \mathrm{~h}$ at $27^{\circ} \mathrm{C}$ in Tris buffer $(50 \mathrm{mM}$ Tris- $\mathrm{HCl} \mathrm{pH} 7.5$ containing $500 \mathrm{mM} \mathrm{NaCl}$ ) containing 0.1 to $1000 \mu \mathrm{g} / \mathrm{mL}$ of tested sample. Sample solvent was used as a control. The assay was initiated by adding HLE fluorogenic substrate MeOSuc-Ala-Ala-Pro-Val-AMC $\left(\lambda_{\mathrm{exc}}=380 \mathrm{~nm} / \lambda_{\mathrm{em}}=460 \mathrm{~nm}\right)$ at a final concentration of $80 \mu \mathrm{M}$. The rate of each substrate cleavage was measured in triplicate for each concentration examined, using an Infinite F200 PRO spectrofluorimeter (Tecan, Lyon, France) with one measure per minute for $60 \mathrm{~min}$. HLE activity was calculated according to the following equation: \% HLE activity $=\left(\right.$ Slope $\left._{\text {sample }} \mathrm{x} 100\right) /$ Slope $_{\text {control }}$, where slope sample $_{\text {and }}$ slope $_{\text {control }}$ are the slope of the fluorescence values as a function of time. Non-linear regression analysis with Graphpad software (La Jolla, USA) allowed us to calculate the $\mathrm{IC}_{50}$.

\section{Conflict of interest}

The authors declare no conflict of interest.

\section{Acknowledgements}

The authors are grateful to ICMR and MEDyC laboratories (University Reims ChampagneArdenne) for having allowed Mrs. Marie Schmitt to be able to perform all the necessary manipulations for the realization of this publication, as well as Grand Est region in France and EU-program FEDER to the PlAneT CPER project for financial support.

\section{References}


Abdul Karim, A., Azlan, A., Ismail, A., Hashim, P., Gani, S. S. A., Zainudin, B. H., Abdullah, N. A., 2014. Phenolic composition, antioxidant, anti-wrinkles and tyrosinase inhibitory activities of cocoa pod extract. BMC Complementary Altern. Med. 14, 1-28.

Aboushoer, M. I., Fathy, H. M., Abdel-Kader, M. S., Goetz, G., Omar, A. A., 2010. Terpenes and flavonoids from an Egyptian collection of Cleome droserifolia. Nat. Prod. Res. 24, 687696.

Al-Snafi, A. E., 2016. The pharmacological and toxicological effects of Coronilla varia and Coronilla scorpioides: a review. Pharm. Chem. J. 3, 105-114.

Arimboor, R., Arumughan, C., 2012. HPLC-DAD-MS/MS profiling of antioxidant flavonoid glycosides in sea buckthorn (Hippophae rhamnoides L.) seeds. Int. J. Food Sci. Nutr. 63, 730738.

Aronne, G., Giovanetti, M., De, M. V., 2012. Morphofunctional traits and pollination mechanisms of Coronilla emerus L. flowers (Fabaceae). The Scientific World Journal 2012, 8 p.

Bicha, S., Benmekhebi, L., Boubekri, N., Khellaf, R., Brouard, I., Zama, D., Benayache, S., Benayache, F., 2016. Compositional study, antibacterial and antioxidant potential of Lepidium draba L. (Brascicaceae). Res. J. Pharm., Biol. Chem. Sci. 7, 283-287.

Bock, K., Pedersen, C., 1983. Carbon-13 nuclear magnetic resonance spectroscopy of monosaccharides. Adv. Carbohydr. Chem. Biochem. 41, 27-66.

Braham, H., Mighri, Z., Ben Jannet, H., Matthew, S., Abreu, P. M., 2005. Antioxidant phenolic glycosides from Moricandia arvensis. J. Nat. Prod. 68, 517-522.

Ceylan, R., Zengin, G., Uysal, S., Ilhan, V., Aktumsek, A., Kandemir, A., Anwar, F., 2016. GC-MS analysis and in vitro antioxidant and enzyme inhibitory activities of essential oil from aerial parts of endemic Thymus spathulifolius Hausskn. et Velen. J. Enzyme Inhib. Med. Chem. 31, 983-990.

Chang, X., Li, W., Jia, Z., Satou, T., Fushiya, S., Koike, K., 2007. Biologically Active Triterpenoid Saponins from Ardisia japonica. J. Nat. Prod. 70, 179-187.

Cui, B., Nakamura, M., Kinjo, J., Nohara, T., 1993. Constituents of leguminous plants. XXXV. Chemical constituents of Astragali Semen. Chem. Pharm. Bull. 41, 178-182.

Deans, B. J., Skierka, B. E., Karagiannakis, B. W., Vuong, D., Lacey, E., Smith, J. A., Bissember, A. C., 2018. Siliquapyranone: A tannic acid tetrahydropyran-2-one isolated from the leaves of carob (Ceratonia siliqua) by pressurised hot water extraction. Aust. J. Chem. 71, 702-707.

Dewick, P. M., Ingham, J. L., 1980. Isopterofuran, a new 2-arylbenzofuran phytoalexin from Coronilla emerus. Phytochemistry 19, 289-291. 
Fierascu, R. C., Ortan, A., Fierascu, I. C., Fierascu, I., 2018. In vitro and in vivo evaluation of antioxidant properties of wild-growing plants. A short review. Current Opinion in Food Science 24, 1-8.

Fujita, T., Funayoshi, A., Nakayama, M., 1994. A phenylpropanoid glucoside from Perilla frutescens. Phytochemistry 37, 543-546.

Guil-Guerrero, J. L., Guil-Laynez, J. L., Guil-Laynez, A., 2017. Bioprospecting for seed oils from wild plants in the Mediterranean Basin for biodiesel production. J. Cleaner Prod. 159, 180-193.

Harborne, J. B., 1981. Two gossypetin methyl ethers as ultraviolet patterning guides in the flowers of Coronilla valentina. Phytochemistry 20, 1117-1119.

Harborne, J. B., Boardley, M., 1983. Trisubstituted flavonol glycosides in Coronilla emerus flowers. Phytochemistry 22, 622-625.

Heywood, V. H., Ball, P. W., 1968. Flora Europaea. Vol. 2 Rosaceae to Umbelliferae. T.G. Tutin. $450 \mathrm{p}$.

Hu, T., Liu, Q.-M., He, X.-W., Huang, F., Zhang, M.-W., Jiang, J.-G., 2017. Identification of bioactives from Astragalus chinensis L.f. and their antioxidant, anti-inflammatory and antiproliferative effects. J. Food Sci. Technol. 54, 4315-4323.

Huang, D. A., 1998. Flora Reipublicae Popularis Sinicae. Vol. 42 (2) Angiospermae Dicotyledoneae Leguminosae. Agendae Academiae Sinacae Edita. 467 p.

Hubert, J., Nuzillard, J.-M., Purson, S., Hamzaoui, M., Borie, N., Reynaud, R., Renault, J.-H., 2014. Identification of Natural Metabolites in Mixture: A Pattern Recognition Strategy Based on 13C NMR. Anal. Chem. 86, 2955-2962.

Ibrahim, T. A., El-Hela, A. A., Abd Elhady, N. M., Abo-Elfetoh, N. M., 2016. Phytochemical composition, in vitro antioxidant and cytotoxic activities of seeds of convolvulus arvensis linn. Int. J. Pharma Bio Sci. 7, 107-116.

Joo, P. K., McKee, G. W., MacDonald, H. A., Langille, R. A., 1975. Isolation and identification of phytotoxic substances from seeds of Coronilla varia L. Proc. Assoc. Off. Seed Anal. 65, 38-51.

Joulain, D., 1986. Study of the fragrance given off by certain springtime flowers. Essential Oil Research 57-67.

Kanlayavattanakul, M., Lourith, N., Kanlayavattanakul, M., Lourith, N., 2018. Skin hyperpigmentation treatment using herbs: A review of clinical evidences. J. Cosmet. Laser Ther. 20, 123-131.

Kazuma, K., Noda, N., Suzuki, M., 2003. Malonylated flavonol glycosides from the petals of Clitoria ternatea. Phytochemistry 62, 229-237. 
Kiem, P. V., Minh, C. V., Nguyen, X. N., Tai, B. H., Quang, T. H., Anh, H. L. T., Nguyen, X. C., Hai, T. N., Kim, S. H., Kim, J. K., Jang, H.-D., Kim, Y. H., 2012. Chemical constituents of the Ficus elastica leaves and their antioxidant activities. Bull. Korean Chem. Soc. 33, 34613464.

Komissarenko, A. N., Kovalev, V. N., 1988. Coronillobiosidol, a cardenolide glycoside from seeds of Coronilla scorpioides. Khim. Prir. Soedin. 24, 619-621.

Kovac, P., Sovova, M., Ryznarova, M., Hojgr, R., Polach, J., 1986. Study on Cornilla varia L. VIII. Identification and determination of free oligosaccharides. Cesk. Farm. 35, 399-403.

Kovalev, V. N., Komissarenko, A. N., 1983. Coronilla varia coumarins and flavonoids. Khim. Prir. Soedin., 235.

Lassen, P., 1989. A new delimitation of the genera Coronilla, Hippocrepis, and Securigera (Fabaceae). Willdenowia 19, 49-62.

Lee, S. Y., Kim, K. H., Lee, I. K., Lee, K. H., Choi, S. U., Lee, K. R., 2012. A new flavonol glycoside from Hylomecon vernalis. Arch. Pharmacal Res. 35, 415-421.

Lehbili, M., Alabdul Magid, A., Hubert, J., Kabouche, A., Voutquenne-Nazabadioko, L., Renault, J.-H., Nuzillard, J.-M., Morjani, H., Abedini, A., Gangloff, S. C., Kabouche, Z., 2018. Two new bis-iridoids isolated from Scabiosa stellata and their antibacterial, antioxidant, anti-tyrosinase and cytotoxic activities. Fitoterapia 125, 41-48.

Lombard, A., Arnal, G., 2000. Hippocrepis emerus (L.) Lassen, 1989. Muséum national d'Histoire naturelle, Conservatoire botanique national $\mathrm{du}$ Bassin parisien, http://www.mnhn.fr/cbnbp accessed November 2018.

Luyen, B. T. T., Thao, N. P., Widowati, W., Fauziah, N., Maesaroh, M., Herlina, T., Kim, Y. H., 2017. Chemical constituents of Piper aduncum and their inhibitory effects on soluble epoxide hydrolase and tyrosinase. Med. Chem. Res. 26, 220-226.

Marquina, J. M. G., Figueras, R. R., 1952. Chemical study of Coronilla emerus. Farmacognosia 12, 49-69.

Moyer, B. G., Pfeffer, P. E., Moniot, J. L., Shamma, M., Gustine, D. L., 1977. Corollin, coronillin and coronarian: three new 3-nitropropanoyl-D-glucopyranoses from Coronilla varia. Phytochemistry 16, 375-377.

Muhammad, D., Lalun, N., Bobichon, H., Le Magrex Debar, E., Gangloff, S. C., Nour, M., Voutquenne-Nazabadioko, L., 2016. Triterpenoids from the leaves of Alphitonia xerocarpus Baill and their biological activity. Phytochemistry 129, 45-57.

Mukherjee, P. K., Maity, N., Nema, N. K., Sarkar, B. K., 2011. Bioactive compounds from natural resources against skin aging. Phytomedicine 19, 64-73.

Nagula, R. L., Wairkar, S., 2019. Recent advances in topical delivery of flavonoids: A review. J. Controlled Release 296, 190-201. 
Opletal, L., Sovova, M., 1986. Studies on Coronilla varia L. VII. Constituents of the herb. Cesk. Farm. 35, 127-129.

Ozden, S., Durust, N., Toki, K., Saito, N., Honda, T., 1998. Acylated kaempferol glycosides from the flowers of Delphinium formosum. Phytochemistry 49, 241-245.

Pandel, R., Poljsak, B., Godic, A., Dahmane, R., 2013. Skin photoaging and the role of antioxidants in its prevention. ISRN Dermatol. 2013, $11 \mathrm{p}$.

Parvez, S., Kang, M., Chung, H.-S., Bae, H., 2007. Naturally occurring tyrosinase inhibitors: mechanism and applications in skin health, cosmetics and agriculture industries. Phytother. Res. 21, 805-816.

Piovan, A., Filippini, R., Innocenti, G., Caniato, R., Cappelletti, E. M., 1996. IX. Coronilla species: In vitro culture and the production of coumarin compounds. Biotechnol. Agric. For. 37, 127-143.

Prochazkova, D., Bousova, I., Wilhelmova, N., 2011. Antioxidant and prooxidant properties of flavonoids. Fitoterapia 82, 513-523.

Purcell, J. M., Morris, S. G., Susi, H., 1966. Proton magnetic resonance spectra of unsaturated fatty acids. Anal. Chem. 38, 588-592.

Roesch, D., Krumbein, A., Muegge, C., Kroh, L. W., 2004. Structural Investigations of Flavonol Glycosides from Sea Buckthorn (Hippophae rhamnoides) Pomace by NMR Spectroscopy and HPLC-ESI-MSn. J. Agric. Food Chem. 52, 4039-4046.

Sartor, L., Pezzato, E., Dell'Aica, I., Caniato, R., Biggin, S., Garbisa, S., 2002. Inhibition of matrix-proteases by polyphenols: chemical insights for anti-inflammatory and anti-invasion drug design. Biochem. Pharmacol. 64, 229-237.

Sharafzadeh, S., 2013. Medicinal Plants as Anti-Ageing Materials: A Review. Glob J. Med. Plant Res. 1, 234-236.

Sherwood, R. T., Shamma, M., Moniot, J. L., Kroschewsky, J. R., 1973. Flavone Cglycosides from Coronilla varia. Phytochemistry 12, 2275-2278.

Sientzoff, P., Hubert, J., Janin, C., Voutquenne-Nazabadioko, L., Renault, J.-H., Nuzillard, J.M., Harakat, D., Alabdul Magid, A., 2015. Fast identification of radical scavengers from Securigera varia by combining 13C-NMR-based dereplication to bioactivity-guided fractionation. Molecules 20, 14970-14984.

Silva, B. A., Malva, J. O., Dias, A. C. P., 2008. St. John's Wort (Hypericum perforatum) extracts and isolated phenolic compounds are effective antioxidants in several in vitro models of oxidative stress. Food Chem. 110, 611-619.

Srinivas, N. R., 2015. Recent trends in preclinical drug-drug interaction studies of flavonoids - Review of case studies, issues and perspectives. Phytother. Res. 29, 1679-1691. 
Torres-Naranjo, M., Suarez, A., Gilardoni, G., Cartuche, L., Flores, P., Morocho, V., 2016. Chemical constituents of Muehlenbeckia tamnifolia (Kunth) Meisn (polygonaceae) and its in vitro $\alpha$-amilase and $\alpha$-glucosidase inhibitory activities. Molecules 21, 1461.

Umehara, K., Hattori, I., Miyase, T., Ueno, A., Hara, S., Kageyama, C., 1988. Studies on the constituents of leaves of Citrus unshiu Marcov. Chem. Pharm. Bull. 36, 5004-5008.

Wang, H., Gao, X. D., Zhou, G. C., Cai, L., Yao, W. B., 2007. In vitro and in vivo antioxidant activity of aqueous extract from Choerospondias axillaris fruit. Food Chem. 106, 888-895.

Williams, J. D., Wojcinska, M., Calabria, L. M., Linse, K., Clevinger, J. A., Mabry, T. J., 2009. The flavonoids and phenolic acids of the genus Silphium and their chemosystematic value. Nat. Prod. Commun. 4, 435-446.

Xiao, Z. P., Wu, H. K., Wu, T., Shi, H., Hang, B., Aisa, H. A., 2006. Kaempferol and quercetin flavonoids from Rosa rugosa. Chem. Nat. Compd. 42, 736-737.

Xie, L.-P., Chen, Q.-X., Huang, H., Wang, H.-Z., Zhang, R.-Q., 2003. Inhibitory effects of some flavonoids on the activity of mushroom tyrosinase. Biochemistry 68, 487-491.

Xu, G.-H., Ryoo, I.-J., Kim, Y.-H., Choo, S.-J., Yoo, I.-D., 2009. Free radical scavenging and antielastase activities of flavonoids from the fruits of Thuja orientalis. Arch. Pharmacal Res. $32,275-282$.

Zhou, J.-T., Li, C.-Y., Wang, C.-H., Wang, Y.-F., Wang, X.-D., Wang, H.-T., Zhu, Y., Jiang, M.-M., Gao, X.-M., 2015. Phenolic compounds from the roots of Rhodiola crenulata and their antioxidant and inducing IFN- $\gamma$ production activities. Molecules 20, 13725-13739. 


\section{Table 1}

Antioxidant, tyrosinase and elastase inhibitory activities of compounds isolated from $H$.

emerus.

\begin{tabular}{|c|c|c|c|c|c|}
\hline & $\begin{array}{c}\text { DPPH radical } \\
\text { scavenging } \\
\text { activity } \\
\text { IC }_{50}(\mu \mathrm{M})\end{array}$ & $\begin{array}{c}\text { OH radical } \\
\text { scavenging } \\
\text { activity } \\
\mathrm{IC}_{50}(\mu \mathrm{M})\end{array}$ & $\begin{array}{c}\text { Power cupric ion } \\
\text { reducing } \\
(\text { CUPRAC }) \\
\text { IC }_{50}(\mu \mathrm{M})\end{array}$ & $\begin{array}{c}\text { Mushroom } \\
\text { tyrosinase } \\
\text { inhibition } \\
\text { IC }_{50}(\mu \mathrm{M})\end{array}$ & $\begin{array}{l}\text { Human neutrophil } \\
\text { elastase inhibition } \\
\text { IC }_{50}(\mu \mathrm{M})\end{array}$ \\
\hline 1 & $(5 \%)^{\mathrm{a}}$ & n.d. & $(34 \%)^{\mathrm{b}}$ & n.d. & n.d. \\
\hline 2 & $(17 \%)^{\mathrm{a}}$ & $888.0 \pm 174.7$ & $617.0 \pm 5.9$ & $(8 \%)^{\mathrm{c}}$ & $769.6 \pm 1.5$ \\
\hline 3 & $(40 \%)^{\mathrm{a}}$ & n.d. & $313.5 \pm 11.2$ & n.d. & $359.5 \pm 1.5$ \\
\hline 4 & $(26 \%)^{\mathrm{a}}$ & $295.0 \pm 5.7$ & $192.6 \pm 12.6$ & $(4 \%)^{c}$ & $265.7 \pm 1.6$ \\
\hline 5 & $219.0 \pm 2.0$ & $110.2 \pm 1.5$ & $47.9 \pm 0.8$ & $(<5 \%)^{\mathrm{c}}$ & $180.3 \pm 1.9$ \\
\hline 6 & $44.4 \pm 3.4$ & $31.1 \pm 0$ & $12.3 \pm 0$ & $(10 \%)^{\mathrm{c}}$ & $258.8 \pm 1.8$ \\
\hline 7 & $(15 \%)^{\mathrm{a}}$ & n.d. & $167.7 \pm 8.2$ & n.d. & $184.1 \pm 1.7$ \\
\hline 8 & $(<50 \%)^{\mathrm{d}, 1}$ & $751.9 \pm 43.7$ & $54.7 \pm 0.8$ & $(<50 \%)^{\mathrm{e}, 2}$ & $86.1 \pm 1.9$ \\
\hline 9 & $28.8 \pm 0.8^{3}$ & $145.8 \pm 4.9^{3}$ & $13.9 \pm 0.8$ & $(<5 \%)^{\mathrm{f}, 4}$ & u. i. ${ }^{5}$ \\
\hline 11 & $83.0 \pm 3.5^{6}$ & $723.2 \pm 38.4$ & $72.8 \pm 0$ & $(13 \%)^{\mathrm{c}}$ & $308.3 \pm 2.8$ \\
\hline 12 & $81.2 \pm 4.9$ & n. d. & $14.5 \pm 0.7$ & n. d. & $165.7 \pm 2.5$ \\
\hline 13 & $(51 \%)^{\mathrm{a}}$ & $1709.2 \pm 913.8$ & $(<5 \%)^{\mathrm{g}, 7}$ & $(<5 \%)^{\mathrm{c}}$ & $693.7 \pm 4.6$ \\
\hline 14 & u.i. $^{8}$ & n.d. & n.d. & $63.4 \pm 2.6^{9}$ & n.d. \\
\hline Quercetin $^{\mathbf{i}}$ & $17.9 \pm 0.7$ & $172.7 \pm 15.9$ & $45.0 \pm 4.3$ & $50.0 \pm 0^{4}$ & $20.0 \pm 0^{5}$ \\
\hline Ascorbic acid ${ }^{i}$ & $13.1 \pm 2.3$ & $1301.5 \pm 13.1$ & $75.5 \pm 2.8$ & & \\
\hline Kojic acid ${ }^{\mathrm{i}}$ & & & & $59.8 \pm 3.5$ & \\
\hline Trolox $^{\mathrm{i}}$ & & & $21.6 \pm 1.2$ & & \\
\hline
\end{tabular}

a $\%$ Inhibition at $200 \mu \mathrm{g} / \mathrm{mL},{ }^{\text {b }} \%$ inhibition at $572 \mu \mathrm{g} / \mathrm{mL},{ }^{c} \%$ inhibition at $1330 \mu \mathrm{g} / \mathrm{mL}$, d $\%$ inhibition at $4.6 \mu \mathrm{g} / \mathrm{mL}$, e $\%$ inhibition at $1000 \mu \mathrm{g} / \mathrm{mL},{ }^{\mathrm{f}} \%$ inhibition at $610.5 \mu \mathrm{g} / \mathrm{mL}, \mathrm{g} \%$ inhibition at $1.4 \mu \mathrm{g} / \mathrm{mL},{ }^{\mathrm{i}}$ used as positive control, n.d. not done, u.i. undetectable inhibition.

${ }^{1}$ Silva et al., 2008, ${ }^{2}$ Muhammad et al., 2016, ${ }^{3}$ Arimboor et al., 2012, ${ }^{4}$ Xie et al., 2003, ${ }^{5}$ Sartor et al., 2002, ${ }^{6}$ Zhou et al., 2015, ${ }^{7}$ Kiem et al., 2012, ${ }^{8}$ Braham et al., 2005, ${ }^{9}$ Luyen et al., 2017. 
Table 2

NMR spectroscopic data of the compounds 1-4 in $\mathrm{CH}_{3} \mathrm{OH}-d_{4}(\mathbf{1 - 2})$ and DMSO- $d_{6}(3-4){ }^{\mathrm{a}}$

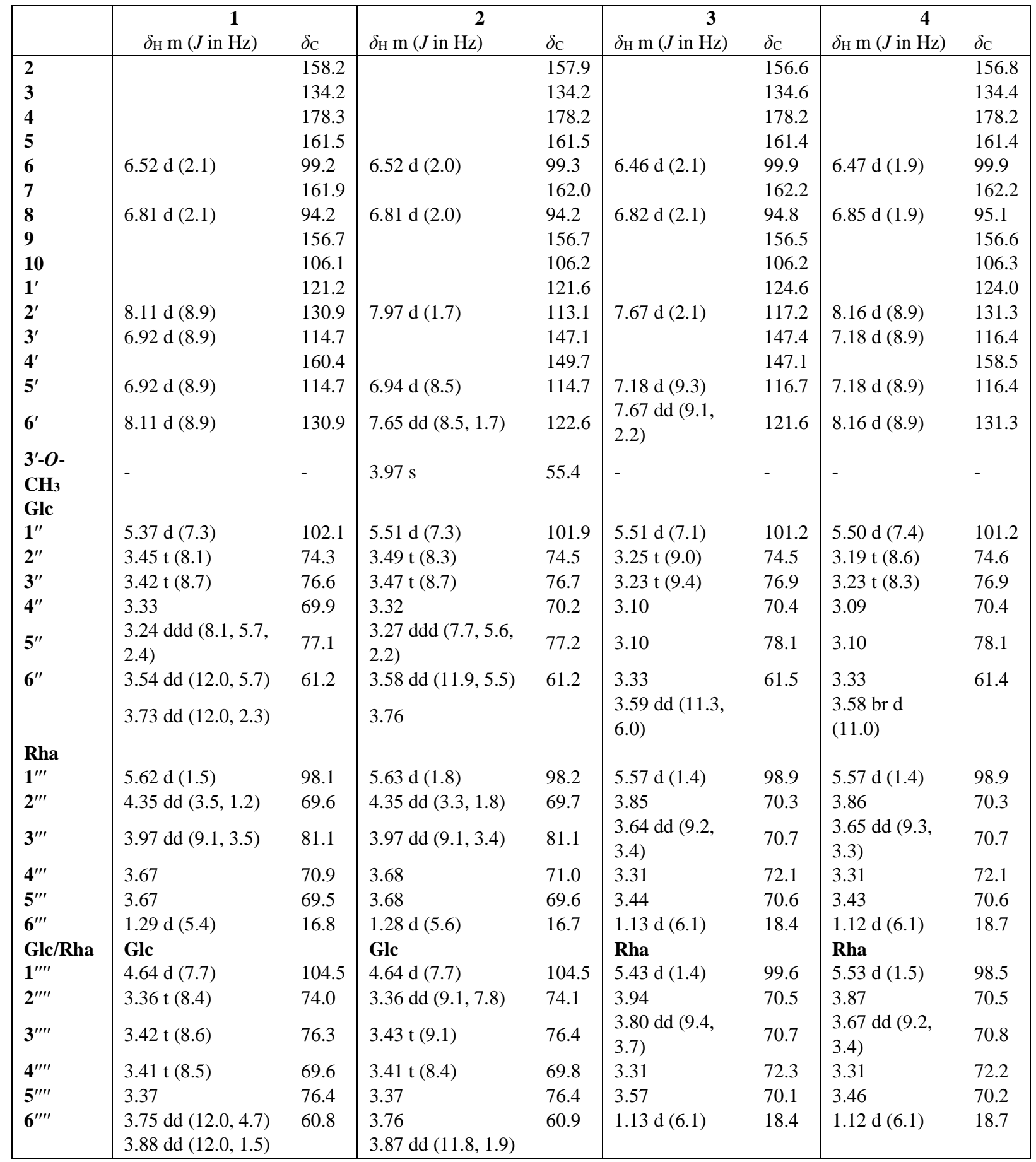

${ }^{a}$ Overlapping ${ }^{1} \mathrm{H}$ NMR signals are reported without designated multiplicity. 


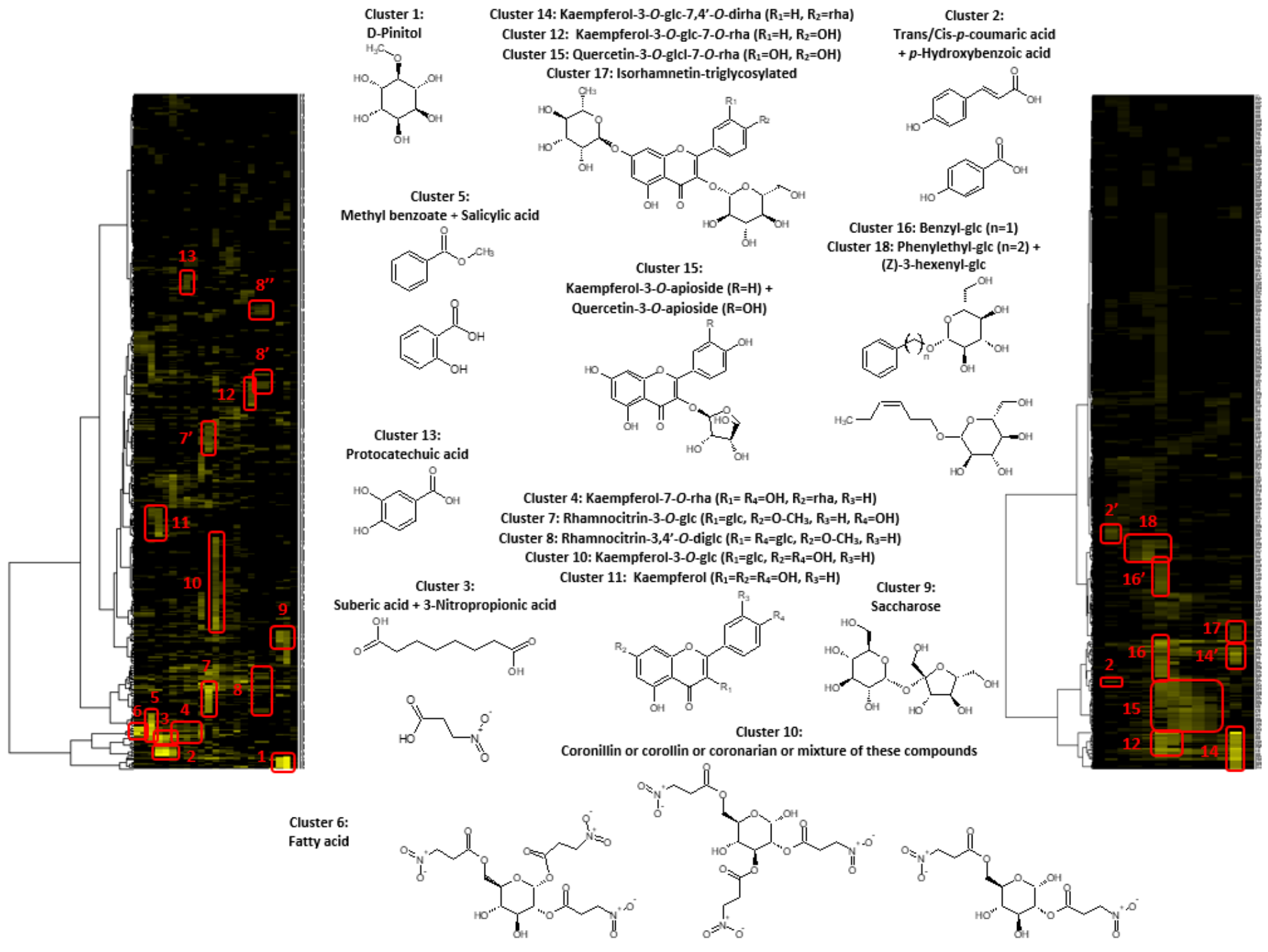

Fig. 1. ${ }^{13} \mathrm{C}$ NMR chemical shift clusters obtained by applying HCA on EAF (left) and $n$-BFD

(right) CPC fractions from H. emerus. 


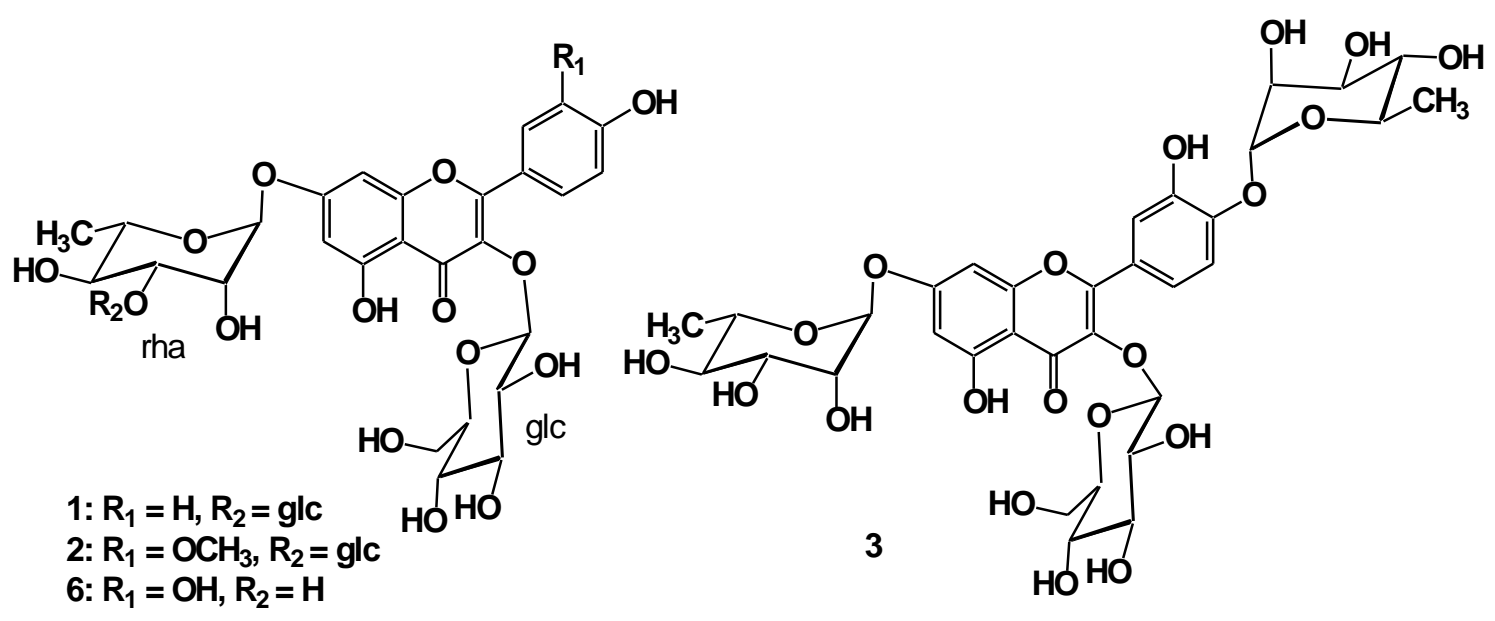<smiles>[R]c1cc(-c2oc3cc(O)cc(O)c3c(=O)c2OC(O)C(O)COC2C(O)C(O)C(O)C(O)C(O)C2O)ccc1O</smiles>

8: $\mathbf{R}=\mathbf{H}$ 9: $\mathrm{R}=\mathrm{OH}$<smiles></smiles>

10: $R=H$

12: $R=$ rha<smiles>OC1COC(OCCc2ccccc2)C(O)C(O)C1O</smiles>

14

Fig. 2. Chemical structures of the three new compounds 1-3 and known bioactive compounds $\mathbf{6}, \mathbf{8}, \mathbf{9}, 10,12$ and 14 isolated from $H$. emerus flowers. 